\title{
O que ajunta espalha: tempo e paradoxo em Grande sertão: veredas, de Guimarães Rosa, e Nós, os do Makulusu, de Luandino Vieira
}

\author{
Júlio Cesar Machado de Paula \\ Doutor em Estudos Literários / UFMG
}

\begin{abstract}
RESUMO
Leitura do tempo e do paradoxo a partir da teoria ricœuriana. Em Grande sertão: veredas, analisa-se a criação de um ponto de observação e elaboração narrativa fora do fluxo temporal. Em Nós, os do Makulusu, estuda-se o processo de desintegração da linearidade temporal em função da experiência traumática da guerra.
\end{abstract}

\section{PALAVRAS-CHAVE}

Tempo, paradoxo, Paul Ricœur, Guimarães Rosa, Luandino Vieira

\section{DA APORIA DO TEMPO À RÉPLICA NARRATIVA}

Em sua densa investigação acerca da natureza e dos mecanismos de funcionamento do tempo, desenvolvida no livro XI das Confissões, Santo Agostinho declara: “O que é, por conseguinte, o tempo? Se ninguém mo perguntar, eu sei; se o quiser explicar a quem me fizer a pergunta, já não sei."1 Com essa síntese admirável, o bispo de Hipona dá voz a uma questão que não nasce com ele e tampouco se esgota em suas reflexões: pressentimos o tempo, mas não somos capazes de defini-lo. De tal questão, classificada por Ricœur como uma "deficiência ontológica do tempo", 2 derivariam outras, de resolução igualmente difícil ou mesmo impossível: possui o tempo uma substância ou sua existência é da ordem da acidentalidade? Se a ideia de tempo está associada à mudança, como tradicionalmente se pensa, haveria um referente estático e único a partir do qual essa mudança seria pressentida? Ou, ao contrário, deve-se buscar um modelo de referentes temporais múltiplos e móveis? A

\footnotetext{
${ }^{1}$ SANTO AgOstinHO. Confissões, p. 322.

${ }^{2}$ RICCEUR. Temps et recit, p. 22. Tomo 1
} 
mudança sugerida pelo tempo é real ou um construto humano? Estamos sujeitos ao tempo ou somos sujeitos dele?

Tal multiplicidade de questões, associada ao repertório igualmente múltiplo de proposições que tentam, ainda que provisoriamente, solucioná-las, permite-nos considerar o tempo como uma categoria de natureza aporética, isto é, que tem início com uma aporia e se desenvolve em torno de outras aporias. De origem grega, o termo aporia (aporía, as) aponta para uma série de definições que se entrelaçam pela ideia comum de impasse, ausência de saída ou, literalmente, "ausência de poros".

É este, sem dúvida, o caso das especulações acerca do tempo, possivelmente, a categoria filosófica mais fluida e heterogênea. Santo Agostinho, encurralado no labirinto construído por sua própria especulação, chega a declarar que desconhece até mesmo aquilo que ignora: "já há muito que falo do tempo e esta demora não é outra coisa senão uma duração de tempo. E como posso saber isto, se ignoro o que seja o tempo? Acontecerá talvez que não saiba exprimir o que sei? Ai de mim, que nem ao menos sei o que ignoro!"3

Ricœur, admitindo o caráter aporético das especulações acerca do tempo, propõe que se dê, em vez de uma resposta absoluta e definitiva, uma réplica narrativa. Diz ele: "a especulação sobre o tempo é uma ruminação inconclusiva, à qual só replica a atividade narrativa. Não que esta resolva, por substituição, as aporias. Se as resolvem, é num sentido poético e não teorético do termo."4

A hipótese de que a tessitura narrativa pode constituir uma réplica poética às aporias do tempo conduzirá, em larga medida, as análises de Grande sertão: veredas, de Guimarães Rosa, e de Nós, os do Makulusu, de Luandino Vieira.

Marcada pelo discurso interior, a narrativa do século 20 experimentou a emergência do narrador em primeira pessoa, não como a testemunha ocular pretensamente neutra dos romances naturalistas, indiferente àquilo que se narra, mas como um perscrutador íntimo de si e de suas interações com o mundo. Sem dúvida, a passagem de uma narrativa focada em uma exterioridade quase cenográfica para uma narrativa que aflora de um mundo interior denso implicou uma série de mudanças na própria estrutura da narrativa, pois, como afirma Mendilow, "para os romancistas, a simetria estática do antigo enredo autônomo não pode

\footnotetext{
${ }^{3}$ SANTO AGOSTINHO. Confissões, p. 333.

${ }^{4}$ RICCEUR. Tempo e narrativa, p. 21. Tomo 1
} 
mais ser imposta sobre o amorfo dinâmico da vida, a qual eles sentem mais como um fluir variável do que como um ser imutável.",5

Em Grande sertão: veredas, o tema do tempo mescla-se ao da travessia e a vários outros que, enredados, fazem avançar a narrativa em uma estrutura densa e reticular. Mesmo uma leitura superficial já revelaria a centralidade da questão, anunciada tanto pela reiteração constante da própria palavra "travessia" e de seus cognatos, quanto por constituir o tema de vários episódios significativos, como a travessia iniciática do rio São Francisco com o menino Reinaldo/Diadorim ou as duas travessias do Liso do Sussuarão. Os próprios limites físicos do texto, isto é, sua abertura e seu encerramento, fazem referência direta ou muito próxima ao tema da travessia. O romance, composto, como se sabe, de um enorme transcurso de fala, abre-se justamente com um sinal gráfico de travessão (-) e se fecha (ainda que de modo não definitivo, como veremos) literalmente com a palavra "travessia" seguida de uma lemniscata $(\infty)$, símbolo gráfico do infinito. Dada essa estrutura, com um texto que se inicia in media res e que, paradoxalmente, fecha-se sugerindo o infinito, ou seja, um não fechamento, os limites acabam por ser relativizados. O texto em si prefigura, dessa forma, uma enorme travessia, em cujo centro deve-se buscar o que é de fato significativo, como o narrador faz questão de dizer: "Digo: o real não está na saída nem na chegada: ele se dispõe para a gente é no meio da travessia."6

Textualmente, é notória a recorrência da ideia da travessia, ora como tema, como no significativo episódio da travessia do São Francisco, quando tem o primeiro contato com Diadorim, ora pela irrupção frequente da própria palavra "travessia". Mas de que travessia se trata? Que travessia é essa para a qual o narrador faz questão de chamar nossa atenção com tanta insistência?

Sabemos que a intenção de Riobaldo, mais do que distrair o pseudointerlocutor que o ouve (e a nós mesmos, como leitores do romance) ou satisfazer-lhe a vontade de saber, pela voz de um barranqueiro e ex-jagunço, o que é o sertão, é especular sobre o sentido de sua própria vivência passada e, a partir dela, sobre grandes questões gerais e seus significados profundos, ocultos pela aparente calma da superfície. "Quem foi que foi que foi o jagunço Riobaldo?", 7 é o que se pergunta o narrador ao longo do texto.

\footnotetext{
${ }^{5}$ MENDILOW O tempo e o romance, p. 8-9.

${ }^{6}$ ROSA. Grande sertão: veredas, p. 65.

${ }^{7}$ ROSA. Grande sertão: veredas, p. 236.
} 
Desde as primeiras páginas, Riobaldo nos enuncia dois princípios fundamentais que nortearão todo o texto e toda a reflexão existencial que por meio dele se desenvolve. Inicialmente, em uma espécie de paráfrase de Heráclito, o narrador formula a noção de que os eventos tornam-se invisíveis para quem os vivencia, obscurecidos que são pela própria turbulência em que se apresentam:

\begin{abstract}
$\mathrm{Ah}$, tem uma repetição, que sempre outras vezes em minha vida acontece. Eu atravesso as coisas - e no meio da travessia não vejo! - só estava era entretido na idéia dos lugares de saída e de chegada. Assaz o senhor sabe: a gente quer passar um rio a nado, e passa; mas vai dar na outra banda é num ponto muito mais embaixo do em que primeiro se pensou. ${ }^{8}$
\end{abstract}

Do embargo da visão em meio à travessia e da consequente impossibilidade de se prever o traçado do percurso que se faz e o ponto de chegada a que somos conduzidos decorre o segundo princípio, reiterado pelo narrador de modo obsessivo: viver, ou seja, cumprir a travessia é algo extremamente perigoso: "O senhor sabe: o perigo que é viver."9

Se viver é algo perigoso e difícil, como insiste o narrador, também a atividade de estruturar o que foi vivido por meio da narrativa o será. Pode-se apontar, aqui, a emergência do tema metalinguístico da dificuldade de elaboração da narrativa, já que esta, como vimos, entrelaça-se à própria vida numa mesma e custosa travessia.

Fraser, ${ }^{10}$ em seu tratado sobre o tempo, reconhece duas abordagens temporais distintas. Por um lado, a exemplo do que temos visto no leitmotif da travessia em Grande sertão: veredas, o tempo seria uma sucessão contínua de instantes, a ponto de não se poder reconhecer um momento distinto como sendo o presente. Por outro lado, invertendo-se a questão, é possível abordar o tempo justamente a partir da estipulação de um momento presente em relação ao qual seja esboçada alguma orientação acerca do passado e do futuro. Para tanto, é imprescindível que a observação do tempo seja feita por alguém que se destaca do próprio transcurso temporal, alçando-se a uma condição de presente dilatado, semelhante à distensão da alma (distentio animi) sugerida por Santo Agostinho. A intenção presente, assim entendida, assume um caráter paradoxal, tornando-se uma espécie de instante de eternidade que abole o transcurso temporal. É o que afirma o narrador a seu ouvinte: "Comigo, as coisas não têm hoje e ant'ontem-amanhã: é sempre."11 Tal afirmação, evidentemente, é cabível

\footnotetext{
${ }^{8}$ ROSA. Grande sertão: veredas, p. 31.

${ }^{9}$ ROSA. Grande sertão: veredas, p. 18.

${ }^{10}$ FRASER. The genesis and evolution of time, p. 86.

${ }^{11}$ ROSA. Grande sertão: veredas, p. 21.
} 
apenas para o Riobaldo especulativo, aquele que, emerso da torrente de eventos que nos envolve no transcurso temporal ininterrupto, pode entregar-se à rememoração do vivido e à sua elaboração em uma teia narrativa rica de sentidos.

Nossa hipótese, pois, é imaginar, a partir do modelo agostiniano de tempo, que Riobaldo, no anseio de assegurar para si próprio alguma tranquilidade, constrói um ponto de intenção presente a partir do qual organiza sua experiência pregressa tumultuada e confusa. Temos, portanto, um princípio de ordenação do tempo e, por extensão, da narrativa, assinalado desde o início por um paradoxo: é preciso sair do fluxo temporal para que se possa dispor o tempo em uma estrutura narrativa apreensível por nosso entendimento. Dessa forma, ao suspender o fluxo do tempo para conferir-lhe alguma ordenação, Riobaldo parece seguir de perto o ensinamento paradoxal de Zé Bebelo, para o qual a única forma de se sair do sertão é entrando por ele adentro.

Um ponto importante a se observar é o fato de que não estamos lidando com um narrador intuitivo, cuja habilidade em contar e recontar estórias pudesse ser considerada inata e que não tivesse, por isso, consciência dos artifícios a que recorre em sua tarefa de efabulador. É o que ele próprio afirma ao seu ouvinte pouco depois do início de sua fala:

De primeiro, eu fazia e mexia, e pensar não pensava. Não possuía os prazos. Vivi puxando difícil de difícel, peixe vivo no moquém: quem mói no aspr'o, não fantasêia. Mas, agora, feita a folga que me vem, e sem pequenos dessossêgos, estou de range rêde. E me inventei neste gosto, de especular idéia. $\mathrm{O}$ diabo existe e não existe? ${ }^{12}$

Adiante, já em uma etapa bastante avançada da narrativa, Riobaldo defende a ideia de que toda tentativa de compreender, com maior ou menor êxito, aquilo que viveu, só é possível graças à estabilidade que a posição presente de fazendeiro the proporciona. E, para exemplificar, vale-se de outra imagem associada à ideia de distanciamento necessário do olhar para a plena compreensão daquilo que se vê. Diz ele: "Sei o grande sertão? Sertão: quem sabe dele é urubu, gavião, gaivota, esses pássaros: eles estão sempre no alto, apalpando ares com pendurado pé, com o olhar remedindo a alegria e as misérias todas." ${ }^{\prime 13}$

A posição de Riobaldo, suspenso como está do tempo e do espaço sertanejos, o afasta de sua condição pregressa, mundana e rasteira, conferindo-lhe o papel de alguém que não é mais apenas um objeto da visão de outrem, mas de quem conduz a narrativa a partir de seu próprio olhar. Posição e papel que se apoiam sobre a concepção metafísica que o criador

\footnotetext{
${ }^{12}$ ROSA. Grande sertão: veredas, p. 11.

${ }^{13}$ ROSA. Grande sertão: veredas, p. 435.
} 
Guimarães Rosa tem da língua, instrumento que, liberto do peso que a banalização cotidiana lhe impõe, cria seus próprios mundos ou corrige o que aí está:

O bem-estar do homem depende do descobrimento do soro contra a varíola e as picadas de cobra, mas também depende de que ele devolva à palavra seu sentido original. Meditando sobre a palavra, ele se descobre a si mesmo. Com isto repete o processo da criação. Disseram-me que isto era blasfemo, mas eu sustento o contrário. Sim! a língua dá ao escritor a possibilidade de servir a Deus corrigindo-o, de servir ao homem e de vencer o diabo, inimigo de Deus e do homem. ${ }^{14}$

Estabelecida a figura de Riobaldo como aquele que, a partir de uma condição sobrelevada (em range rede), estrutura pela narrativa uma determinada vivência (travessia), cabe verificar se esse modo de olhar nos permite imaginar um modelo de estruturação temporal e, portanto, narrativo, aplicável à forma como Riobaldo apresenta os elementos que lhe servem de material narrativo.

Por se tratar de uma narrativa de cunho memorialístico, uma característica comum acompanha praticamente todos os modelos temporal-narrativos propostos para Grande sertão: veredas: a ideia de retorno, de recursividade. Em um primeiro momento, imaginou-se uma narrativa que, ao romper com a linearidade progressiva, se aproximasse da imagem de um círculo. É o que faz Campos ao afirmar que "o esquema circular, da narrativa que propõe um retorno sobre si mesma, não está afastado da estrutura do Grande sertão". ${ }^{15}$ Como resultado, teríamos uma "elisão da estrutura linear (princípio-meio-fim) e da unidade temporística, que cedem lugar a uma forma aberta, atemporal, aperspectivística". ${ }^{16}$

Uma solução possível seria imaginar a recorrência a partir de um modelo elíptico, como o faz Diniz. ${ }^{17}$ Diferentemente do círculo, com seu centro único e imutável, a elipse, como figura geométrica, caracteriza-se pela presença de dois pontos focais cujas distâncias que os separam da curva têm soma constante. Como modelo narrativo de Grande sertão: veredas, teríamos também uma dupla perspectiva, relativizando ou mesmo eliminando a ideia de centro único e de rota circular. Riobaldo, senhor da palavra, ocuparia, como narrador, o ponto principal. Diadorim, com sua presença indecifrável e desconcertante, funcionaria como um segundo ponto, promovendo uma espécie de refração narrativa capaz de transformar o que seria circular em uma elipse.

\footnotetext{
${ }^{14}$ Citado por LORENZ. Diálogo com Guimarães Rosa, p. 83-84.

${ }^{15}$ CAMPOS. Augusto de. Um lance de "dês" do Grande sertão, p. 13.

${ }^{16}$ CAMPOS. Augusto de. Um lance de "dês" do Grande sertão, p. 13.

${ }^{17}$ DINIZ. A figura da elipse no Grande sertão: veredas, p. 175.
} 
No entanto, o modelo elíptico, ainda que mais adequado que o circular, também se mostra insuficiente para a compreensão dos volteios de que se vale Riobaldo. Uma órbita de eventos que fosse descrita pela elipse não obedeceria à equidistância de um ponto central único, como no círculo, mas seria sempre a mesma a cada nova volta. Ou seja, emprestaria à narrativa um caráter de previsibilidade que em nada lembra a escrita rosiana. Ao contrário, o próprio narrador, em suas incursões metalinguísticas, destaca a necessidade de emendar constantemente a narrativa, já que os eventos passados não são estáveis e se mostram distintos a cada nova incursão pela memória. "O senhor sente? Desmente? Eu desminto. Contar é muito, muito dificultoso. Não pelos anos que já se passaram. Mas pela astúcia que têm certas coisas passadas - de fazer balancê, de se remexerem dos lugares." ${ }^{18}$ Além disso, a imagem da elipse, como a do círculo, caracteriza-se por ser uma figura fechada, o que bate de frente com a ideia de narrativa aberta, como é Grande sertão: veredas, com seu início in media res e sua sugestão final de infinito.

Como conciliar, pois, a recorrência que caracteriza o tom memorialístico do romance e a proposta de abertura para o infinito que ele mesmo nos faz? Uma sugestão nos pode ser dada a partir da imagem de que se vale Riobaldo para descrever o ponto de visão a partir do qual sua narrativa é elaborada: a rede em suspensão. Se imaginarmos o balanço da rede como único movimento possível, teremos uma ideia de pêndulo, de algo que se desloca preso a um eixo suspenso e que retorna ciclicamente a pontos cada vez mais próximos desse mesmo eixo. Ora, a curva descrita por tal movimento não é circular nem elíptica, mas espiralada. Sabemos pelos comentários do próprio Riobaldo que a versão por ele apresentada ao homem letrado da cidade (exatamente a que nos chega pela leitura) já está profundamente modificada pelas inúmeras considerações (ou até mesmo reparos) feitas pelo compadre Quelemém, ouvinte anterior da longa narrativa. Não nos parece estranho presumir que uma nova e hipotética elaboração da narrativa, feita por Riobaldo a outro ouvinte, já incorpore as considerações do homem citadino, e assim sucessivamente, em um movimento espiralado que sugere a possibilidade de condução da narrativa ao infinito.

A hipótese de que a figura da espiral adequa-se à estrutura narrativa de Riobaldo ganha respaldo na presença constante da imagem do redemoinho, apresentada ao leitor já na epígrafe do livro:

"O diabo na rua
no meio

${ }^{18}$ ROSA. Grande sertão: veredas, p. 142. 
do redemoinho"19

Campos $^{20}$ aponta que Rosa, a exemplo de Lewis Carrol, recorre com frequência ao uso de palavras portmanteau, ${ }^{21}$ formadas a partir da junção de outras palavras cujos sentidos distintos (e, não raro, contrários) são unidos para expressar novas ideias. Tal procedimento de construção se mostraria enriquecedor justamente por desencadear, dentro de um mesmo vocábulo, uma série de conflitos semânticos capazes de potencializar os níveis de significado envolvidos.

É justamente o caso de "redemoinho" no contexto de Grande sertão: veredas. Como fenômeno natural, a palavra é definida por Caldas Aulete como "cruzamento de correntes contrárias de água ou de vento." 22 Separando-se as duas primeiras sílabas das demais, obtêmse "rede" e "moinho", dois novos vocábulos cujos campos semânticos se opõem. Se "rede" implica as ideias de unidade, tessitura, reunião, síntese e ação simbólica, "moinho", ao contrário, sugere pó, dispersão, desagregação, diálise, ação diabólica. Mas a riqueza do vocábulo não se esgota no jogo paradoxal que "rede" e "moinho" estabelecem entre si. Se ao invés de dividirmos a palavra observarmos o seu miolo, tomando, para isso, a última sílaba de "rede" e a primeira de "moinho", "reDEMOinho", o que se tem é justamente "demo", assentado no meio da palavra como seu próprio ser no centro da espiral (e esta no centro da rua, e assim por diante, conduzindo a espiral para o infinito). Ao se chegar ao centro da espiral simbólica, ao olho do redemoinho, ao ponto exato em que deveriam ser atados os fios que para ali convergiram, descortina-se a figura do diabo, o diabolo, aquele que desagrega, que dispersa o que fora reunido: o diabo na rua, no meio do redemoinho. A rede elaborada por Riobaldo desfia no momento exato de ser concluída. Mas, juntos, os contrários não se anulam e dão lugar a uma metáfora viva, a do redemoinho diabólico, que ultrapassa o vocábulo composto e a epígrafe em que primeiro aparecem e espraia-se por todo o romance para compor o "mundo movente" 23 e "misturado" 24 de Riobaldo. Por essa razão, vemos ressurgir a imagem do redemoinho nos principais momentos da narrativa, como na cena do suposto pacto

\footnotetext{
${ }^{19}$ ROSA, Grande sertão: veredas, p. 7.

${ }^{20}$ CAMPOS. Um lance de "dês" do Grande sertão. p. 10

${ }^{21}$ Segundo a Merriam-Webster encyclopedia of literature, Carrol foi o primeiro a usar a expressão, no intuito de explicar seu próprio processo de composição lexical. Em português, costuma-se usar o termo "palavra-valise", traduzido do francês mot-valise, com o mesmo sentido.

${ }^{22}$ AULETE. Dicionário contemporâneo da língua portuguesa, p. 3.482.

${ }^{23}$ GARBUGLIO. O mundo movente de Guimarães Rosa.

${ }^{24}$ ARRIGUCCI. O mundo misturado: romance e experiência em Guimarães Rosa.
} 
de Riobaldo com o diabo: "Nós dois, e tornopío do pé-de-vento - o ró-ró girando mundo a fora, no dobar, funil de final, desses redemoinhos: ... o Diabo na rua, no meio do redemunho...!"'; ${ }^{25}$ e no embate final entre Diadorim e Hermógenes, assinalado pela presença nefasta e anunciadora do tufão, antevisto por Riobaldo: "Trecheio, aquilo rodou, encarniçados, roldão de tal, dobravam para fora e para dentro, com braços e pernas rodejando, como quem corre, nas entortações. ... O diabo na rua, no meio do redemunho..."26

\section{ENTRE A METÁFORA E O PARADOXO}

Em 1965, por ocasião do "Congresso Latino-Americano de Escritores”, realizado em Gênova, Guimarães Rosa concedeu ao jornalista alemão Günter Lorenz uma de suas raras entrevistas. Questionado acerca do uso (excessivo, no entendimento de Lorenz) de paradoxos, tanto em sua fala quanto em sua obra, o escritor brasileiro afirma categoricamente: "a vida, a morte, tudo é, no fundo, paradoxo. Os paradoxos existem para que ainda se possa exprimir algo para o qual não existem palavras." ${ }^{27}$ Longe de ser apenas uma resposta irônica a uma pergunta impertinente, as palavras de Rosa fazem uma dupla revelação.

Por um lado, no campo conceitual, afigura-se uma concepção do mundo como algo paradoxal; em seguida, avançando sobre o terreno da escrita como forma de expressão, tem-se a definição do paradoxo como recurso possível (se não o único) diante das insuficiências da linguagem. O papel atribuído por Rosa ao paradoxo é surpreendente por aproximá-lo da metáfora em uma de suas funções originais. Evidentemente, não estamos pensando, aqui, na metáfora reduzida a mero tropo de ornamentação do discurso, na metáfora concebida como simples substituição de uma palavra por outra no bojo da frase, mas como um princípio de instauração e enriquecimento da própria linguagem.

Uma das ideias sustentadoras da teoria de Ricœur sobre a metáfora é a hipótese de I. A. Richards de que ela, a metáfora, não é um mero tropo de ornamentação do discurso, mas o próprio "princípio onipresente da linguagem". ${ }^{28}$ Analisar, portanto, como um autor elabora suas metáforas pode dar indícios de como se constitui a linguagem mesma desse autor.

\footnotetext{
${ }^{25}$ ROSA. Grande sertão: veredas, p. 318-319.

${ }^{26}$ ROSA. Grande sertão: veredas, p. 450.

${ }^{27}$ Citado por LORENZ. Diálogo com Guimarães Rosa, p. 68.

${ }^{28}$ RICHARDS. The philosophy of rhetoric, p. 92.
} 
Como aponta Pouillon, as personagens literárias existem, antes de tudo, em função do olhar que o narrador lança sobre elas, tratando-se, por isso, de uma "existência em imagem". ${ }^{29}$ A partir dessa consideração, pode-se dizer que Riobaldo, como personagem, existe em função do olhar que deita sobre si mesmo e do caráter especulativo de sua narrativa, que lhe serve de dispositivo reflexivo, espécie de espelho textual pelo qual Riobaldo torna-se capaz de vislumbrar a si mesmo como um outro.

Contudo, a tarefa de constituir a própria imagem por meio da narrativa não se apresenta como das mais fáceis, tornando o questionamento existencial um dos temas centrais do livro. A insistência com que as interrogações do narrador acerca de seu próprio ser surgem na narrativa já aponta para a dificuldade de se obter uma resposta, senão definitiva, ao menos provisoriamente convincente. A observação de dois momentos em que Riobaldo formula diretamente a questão pode nos revelar um dispositivo importante nessa busca: "O jagunço Riobaldo. Fui eu? Fui e não fui. Não fui! - porque não sou, não quero ser. Deus esteja!"30 “O senhor pergunte: quem foi que foi que foi o jagunço Riobaldo?"31

No primeiro caso, vê-se que a questão surge com o verbo "ser" conjugado na primeira pessoa e acompanhado de um pronome pessoal correspondente (“fui eu?”), de modo a manter unidos, como um mesmo ente, o narrador-especulador e a personagem sobre a qual se especula. Adiante, contudo, ao retomar o mesmo questionamento existencial, valendo-se, inclusive, de uma estrutura sintática semelhante, Riobaldo o faz em terceira pessoa ("quem foi?”), como se o narrador já não se confundisse com a figura de Riobaldo como personagem de sua própria trama.

Ao tratarmos da questão do ponto de partida do olhar de Riobaldo, vimos que ele compõe para si próprio a imagem de alguém que, destacado do espaço sertanejo e do tempo em que se deram os eventos narrados, entrega-se à tarefa de "especular ideia". Riobaldo é, pois, conforme suas próprias palavras indicam, um especulador. Alçado à condição de rangerede, Riobaldo é o narrador e o espelho, aquele que narra e aquele que especula; como personagem, é visto por si próprio como alguém que tem a vida narrada e sobre quem se especula. Riobaldo faz-se outro para chegar a si-mesmo. Nesse ponto, já é inquestionável a cisão promovida pelo narrador em seu próprio ser.

\footnotetext{
${ }^{29}$ POUILLON. O tempo no romance, p. 56.

${ }^{30}$ ROSA. Grande sertão: veredas, p. 166.

${ }^{31}$ ROSA. Grande sertão: veredas, p. 236.
} 


\section{LUANDINO VIEIRA E A NARRATIVA “DE UM SÓ JACTO”}

Vimos anteriormente como Riobaldo organiza sua experiência tensa e tumultuada do passado a partir de uma condição presente diversa, caracterizada justamente pela estabilidade de um narrador que ocupa uma posição sobrelevada, alheia ao fluxo temporal. Há, pois, um princípio estruturador do tempo constituído a partir de uma intenção presente que se destaca do próprio tempo para poder observá-lo. Algo semelhante pode ser visto em João Vêncio: os seus amores, romance de Luandino Vieira que guarda mais similaridades com Grande sertão: veredas, a começar pelo narrador, uma figura popular semiletrada que tece sua autobiografia diante de um pseudointerlocutor letrado. A condição de detentos em que ambos se encontram cria uma espécie de estancamento do fluxo do tempo e da vida, de modo semelhante ao que ocorre com Riobaldo em sua condição de "range rede".

O mesmo, contudo, não se observa em Nós, os do Makulusu. Ao ser questionado sobre o processo criativo empregado na composição do romance, Luandino Vieira confirma que o livro foi escrito em apenas uma semana, de 16 a 23 de abril de 1967, no campo de concentração do Tarrafal, em Cabo Verde, conforme a indicação no final do romance. E acrescenta: "Foi escrito de um só jacto", isto é, "foi escrita de uma só vez, com os intervalos naturais, humanos." 32 A afirmação de Luandino a respeito dessa escrita "de um só jacto" poderia parecer fortuita, um mero informe extratextual típico dos almanaques de efemérides literárias. $\mathrm{O}$ autor assevera, contudo, que, ainda que não o tenha planejado, trata-se de seu romance em que o assunto de que se compõe a narrativa está mais intensamente relacionado com a forma narrativa em que foi vazado. ${ }^{33} \mathrm{E}$ o tema precípuo do romance, bem o sabemos, é o conflito de independência que divide a família de colonos portugueses. Como cerne temático capaz de dilacerar a própria forma do romance, o conflito impede que se crie uma intenção presente ou um ponto privilegiado de observação a partir do qual se pudesse organizar o fluxo temporal. Como nos informa uma cantiga ouvida por Mais-Velho na infância, a guerra leva-nos os olhos e o resto: "Perdi meus olhos na guerra / Com eles tudo perdi.... 34

${ }^{32}$ Citado por LABAN et al. Luandino. José Luandino Vieira e sua obra (estudos, testemunhos, entrevistas), p. 30-31.

${ }^{33}$ Citado por LABAN et al. Luandino. José Luandino Vieira e sua obra (estudos, testemunhos, entrevistas), p. 32.

${ }^{34}$ VIEIRA. Nós, os do Makulusu, p. 57. 
Para Meyerhoff, o recurso à livre associação como procedimento de escrita desencadeia "um simbolismo ou imagística no qual as diferentes modalidades de tempo passado, presente e futuro - não sejam serial, progressiva e uniformemente ordenadas e sim sempre inextricável e dinamicamente associadas e mescladas umas às outras". 35 É o que se vê em Nós, os do Makulusu desde o primeiro parágrafo do romance, no qual o narrador opera uma transposição extremamente sutil em direção ao passado, sugerida pelo movimento ondulante do caixão em que vai o corpo do irmão. Conduzido por pessoas de alturas diferentes, Mais-Velho tem a impressão de que o esquife se alteia e se abaixa, parecendo descrever um movimento ondulante de um barco, ou, mais precisamente, do barco em que estiveram juntos no passado:

Levado por quatro mãos que são de alturas, andares, passos, sentimentos diferentes e ensinam no caixão ondular de barco em mar de calema e o Maninho deve de estar mareado, era isso, mareado e eu disse-lhe então:

- Cagunfas! $!^{36}$

Trata-se, portanto, da possibilidade de deslocamentos temporais bastante livres que ora recuam e ora avançam, ou, nas palavras do autor, de um "fluxo de memória que, por um lado, como fluxo de memória, se alimenta do passado e, por outro lado, tem avanços, digamos irreais sobre o futuro". 37

Antes mesmo de tomarmos contato com a desconcertante prosa de Nós, os do Makulusu, chama-nos a atenção a presença, já no título, de um topônimo quimbundo, Makulusu, apresentado em sua ortografia antiga. Segundo informação de Lobo, ${ }^{38}$ o termo, nome de um antigo musseque de Luanda, pode ser traduzido para o português como "cruzes". O nome foi aplicado ao local pelo fato de os portugueses terem instalado ali, em tempos remotos, o Cemitério do Alto das Cruzes, cenário do último bloco narrativo de Nós, os do Makulusu. Assim, o caminho percorrido pelo féretro de Maninho, personagem nuclear do romance, é, literalmente, uma Via Crúcis, um caminho das cruzes. Paradoxalmente, o Makulusu é tanto o espaço idílico da infância, o cenário da celebração do pacto de comunhão que, a exemplo do pronome do título do romance, uniu os quatro amigos, quanto o espaço que oferecerá o seu chão para a transformação definitiva do corpo de Maninho em pó.

\footnotetext{
${ }^{35}$ MEYERHOFF. O tempo na literatura, p. 22.

${ }^{36}$ VIEIRA. Nós, os do Makulusu, p. 13.

37 Citado por LABAN et al. Luandino. José Luandino Vieira e sua obra (estudos, testemunhos, entrevistas), p. 32.

${ }^{38}$ LOBO. Subsídios para a história de Luanda, p. 207.
} 
Seria errôneo imaginar que a disposição da narrativa em tais passos pudesse servir como uma espécie de esteio estrutural diante da evidente fragmentação temporal experimentada pelo narrador. O próprio termo "musseque", que significa literalmente "lugar de areia", ${ }^{39}$ nos sugere a ideia de que a tênue linha espacial do Makulusu que une a infância e a morte pode ser facilmente dispersa pelo próprio deslocamento do passado e do futuro.

A ideia de um caminho percorrido tanto pelo passado quanto pelo futuro já se encontra prefigurado na epígrafe em quimbundo utilizada por Luandino Vieira: “... mukonda kutuatundu kiá, kî tutena kumona-ku dingi kima. O kima, tu-kisanga, kiala ku tuala um ia., Trata-se do fragmento de um missosso, narrativa tradicional angolana que se caracteriza, dentre outros elementos, pela presença de uma fórmula de abertura, "eme ngateletele", que, segundo indicação do próprio Luandino Vieira, significaria algo como "reunir vários tempos". 41

A dissolução da origem portuguesa pode ser vista no episódio em que Mais-Velho, dentro da igreja, passa a descrever uma antiga fotografia de família, desbotada pelo tempo, manchada pela umidade e com a indicação de quando foi tirada: "1 de janeiro de mil novecentos e trinta e qualquer coisa esbatida num pingo de água à toa." ${ }^{42}$ A imagem não deixa dúvidas: a origem europeia, sujeita ao tempo e ao contato com o outro, torna-se cada vez mais líquida e mais turva.

Mas a passagem da origem portuguesa para o novo contexto histórico-cultural não se dá de modo abrupto, exigindo uma ritualística própria, pois, como afirma Mais-Velho, "filho de colono tem de aprender os ritos e os mitos". 43 É o que se pode ver no episódio iniciático da caverna do Makokaloji, espécie de útero africano no qual mergulham Mais-Velho, Maninho, Paizinho e Kibiaka para realizarem, ali, um pacto de união que os transformará em Nós, os do Makulusu.

A ideia de que se trata de um novo nascimento fica explícita quando o narrador compara a entrada da caverna a uma "vagina da terra, barroca descabassada por nós". Lá, os quatro meninos derramam o seu sangue e fazem um juramento de fidelidade, emergindo

\footnotetext{
${ }^{39}$ HOUAISS. Dicionário eletrônico Houaiss da língua portuguesa, verbete 'musseque'.

${ }^{40}$ VIEIRA. Nós, os do Makulusu, p. 11. (grifos do autor)

${ }^{41}$ Citado por PERES. Transculturation and resistance in lusophone African literature, p. 23.

${ }^{42}$ VIEIRA. Nós, os do Makulusu, p. 71

${ }^{43}$ VIEIRA. Nós, os do Makulusu, p. 101.
} 
depois não mais como quatro indivíduos isolados, mas como um grupo que se supõe indissolúvel.

A heterogeneidade do grupo atesta a vontade de se criar não apenas um espaço comum, mas um futuro em que as diferenças não sejam motivo de atritos constantes. Assim, podem fazer parte do mesmo rito, do mesmo renascimento, figuras diferentes como MaisVelho e Maninho, brancos e filhos de colonos portugueses; Paizinho, o meio-irmão mestiço, filho do pai com uma negra angolana; e Kibiaka, o negro angolano, filho da terra. Nesse sentido, a descida conjunta ao Makokaloji, ao ventre africano, pode ser entendida como um processo de esquecimento das origens distintas com o intuito de se assegurar um futuro comum.

O contraste entre a imagem da fotografia de família, a apontar para uma origem que aos poucos se desbota, e a sagração do pacto de união futura feito no Makokaloji, remete-nos, novamente, à sugestão dada pela epígrafe de que o importante não é o "de onde viemos", mas o "para onde vamos". Mas o que nos espera por lá?

Podem-se reconhecer em Nós, os do Makulusu duas modalidades distintas de investida sobre o futuro. No primeiro caso, que podemos chamar de futuro do pretérito, o ponto de que parte a narração desloca-se para o passado e, de lá, passa a relatar eventos situados temporalmente à frente desse ponto, mas anteriores ao dia do enterro de Maninho. Bastante frequente, tal modalidade assoma à narrativa, na maioria dos casos, como uma revelação paradoxal do desconhecimento de algo que ainda está por acontecer.

Diferentemente da primeira, a segunda modalidade de avanço sobre o tempo caracteriza-se, no romance Nós, os do Makulusu, por um deslocamento para um ponto à frente do dia do funeral de Maninho. Estamos, pois, em um plano de futuro que já não é apenas linguístico, implicando um processo premonitório, que, apesar de fictício, é associado por Luandino Vieira ao próprio curso da História. Diz ele:

Há uma espécie de premonição. Isso é o que, em termos de estrutura narrativa, penso que seja o sentido histórico. A visão da história que faz com que o narrador invente e minta em relação ao futuro que ele ainda não conhece, mas que põe como se já soubesse que vai suceder assim. ${ }^{44}$

O primeiro exemplo significativo pode ser dado pelo episódio em que Mais-Velho projeta-se dez anos em direção ao futuro, momento em que se encontra com a irmã caçula, Maria, em Portugal. É significativo o fato de Mais-Velho estar ausente de Angola por essa

${ }^{44}$ Citado por LABAN et al. Luandino. José Luandino Vieira e sua obra (estudos, testemunhos, entrevistas), p. 32. 
altura, 1973, momento de intensificação dos combates pela independência. Tal ausência parece confirmar as críticas feitas por Maninho ao irmão mais velho, com seus preceitos que não passam de uma "moralzinha para uso próprio", ${ }^{45}$ baseados em um marxismo de muitas palavras e pouca ação, ou mesmo ações contraditórias, como nos informam as ironias do irmão caçula: "Lês Marx e comes bacalhau assado, não é? Não te deitas com negras nem mulatas." 46

Além disso, Mais-Velho, que, por coerência ao seu próprio discurso, deveria engajarse às lutas de independência, como Paizinho e Kibiaka, encontra-se no futuro justamente em companhia da personagem que representa o repúdio máximo aos valores africanos. Nascida já em Angola, em São Paulo de Luanda, a irmã caçula vangloria-se por ter conseguido alterar sua certidão de nascimento, eliminando a palavra Luanda, "que cheira a catinga, a negros, a comerciantes, a fuba, a escravos e sangue", ${ }^{47}$ e acrescentando "da Assumpção". Dessa forma, ao menos do ponto de vista burocrático, ela se faz passar por portuguesa e inverte o caminho seguido pelos pais e pelos irmãos mais velhos. O fenômeno de exclusão do termo português de seu documento de registro pode ser confrontado ainda com o que ocorre com o nome da igreja de Nossa Senhora do Carmo, que, devido ao local em que foi construída, teve adicionado a seu nome um termo africano, tornando-se Nossa Senhora do Carmo da Ingombota.

As investidas em direção ao futuro atingem seu ponto mais tenso no quarto bloco narrativo, momento em que o cortejo de Maninho chega a seu destino final, o Cemitério do Alto das Cruzes. A sequência desenvolvida neste espaço toma como ponto de partida as palavras litúrgicas tradicionalmente proferidas em cerimônias fúnebres: Memento homo, quia pulvis es, et in pulverem reverteris.

Luandino Vieira, leitor declarado de Antonio Vieira, também promoverá, a partir da citação litúrgica, uma espécie de união dos tempos, mas sob o signo da ironia e da dessacralização. Esta se dá pelo trocadilho erótico composto pelo narrador ao associar pulvis, o pó da citação latina, a púbis. O trocadilho não apenas dessacraliza o caráter litúrgico da cerimônia, mas estabelece uma aproximação entre a morte (pulvis) e o nascimento (púbis). Tal aproximação, evidentemente, não é fortuita e está acompanhada de uma das imagens mais fortes do livro: a de Maninho exposto como escultura.

\footnotetext{
${ }^{45}$ VIEIRA. Nós, os do Makulusu, p. 14.

${ }^{46}$ VIEIRA. Nós, os do Makulusu, p. 28.

${ }^{47}$ VIEIRA. Nós, os do Makulusu, p. 49.
} 
De súbito, a memória de Mais-Velho abandona o cemitério e voa para uma exposição de arte surrealista realizada em 1953 no Palácio dos Fantasmas, antiga sede administrativa colonial localizada na Rua das Flores. Considerando a exposição insatisfatória, Mais-Velho salta em direção ao futuro e apresenta-se como "irmão dum alferes morto da guerra de Angola", desejoso de expor ali uma escultura. Ironicamente, o nome da escultura, "Deus, Pátria e Família", ${ }^{48}$ zomba de valores caros ao conservadorismo salazarista. Pela proposta, o governador cortaria a fita de abertura da exposição, que poderia ser, paradoxalmente, "uma fita de metralhadora ou o umbilical cordão de uma mulher". ${ }^{49}$ E, na sala de exposição, a escultura: Maninho, preso por correntes de escravo, a flutuar dentro de um enorme útero feito de plástico branco made in USA e repleto não de liquido amniótico, mas de cerveja. Assim, Maninho é, a um só tempo, aquele que morre em decorrência da guerra e aquele que vai nascer sob o signo do imperialismo. A terrível imagem de Maninho sendo gestado em um útero de cerveja, atado por um cordão umbilical que pode ser um feixe de balas de metralhadora, como a fita inaugural da exposição, leva-nos a refletir sobre as expectativas a respeito de Angola, país então nascituro. Whitrow, ${ }^{50}$ analisando as relações entre o tempo e a cognição, observa que, ao nascermos, somos desprovidos de memória; tudo é ainda uma enorme expectativa, que a experiência cotidiana transformará, por seu turno, em memória. A imagem de Maninho como um enorme feto-cadáver parece inverter essa lógica, servindo alegoricamente como o emblema de um país que já nasce assinalado por estigmas da violência. Não por acaso, a descrição da escultura encerra-se com a seguinte frase de MaisVelho: "O sono na história vai parir mais monstros.",51

\section{CAMINHOS DO CONTEMPORÂNEO}

Em seu Livro dos seres imaginários, Jorge Luis Borges dedica duas páginas à descrição da "Fauna dos Estados Unidos". Do grupo de animais ali descritos, chama nossa atenção o Goofus bird, "pássaro que constrói o ninho ao contrário e voa para trás, porque não lhe importa aonde vai, mas sim onde esteve". ${ }^{52}$ À parte o que a imagem possa ter de irônica, o

\footnotetext{
${ }^{48}$ VIEIRA. Nós, os do Makulusu, p. 105

${ }^{49}$ VIEIRA. Nós, os do Makulusu, p. 104.

${ }^{50}$ WHITROW. O tempo na historia: concepções sobre o tempo da pré-história aos nossos dias, p. 17.

${ }^{51}$ VIEIRA. Nós, os do Makulusu, p. 105.

${ }^{52}$ BORGES. O livro dos seres imaginários, p. 73.
} 
pássaro norte-americano, com sua obsessão pela própria origem, sugere-nos uma imagem inquestionável de atavismo, uma vez que ele nada vislumbra além de sua própria origem.

Em um sentido determinista quase oposto, Quelemém, o compadre kardecista de Riobaldo, recomenda ao narrador de Grande sertão: veredas que volte seu olhar para frente, ou seja, para o futuro, buscando despertar-lhe a confiança no progresso positivo da História.

Nesse contexto adverso, dividido entre um olhar exclusivamente passado e um olhar exclusivamente futuro, o contemporâneo emerge como uma possibilidade de se refletir sobre o tempo, sem se deixar levar por um determinismo atávico, como o do goofus bird, ou por um determinismo preso à ideia evolucionista de progresso, como o de Quelemém. Cabe então perguntar: o que é o contemporâneo?

Buscando responder a essa pergunta, Agamben recorre a uma definição dada por Nietzsche em suas "Considerações intempestivas”. Diz o filósofo alemão: "O contemporâneo é o intempestivo." 53 É mister, contudo, perguntar: intempestivo com relação a quê? A uma cultura histórica do presente, responderia Nietzsche. Para ele, o apego ao tempo presente, longe de ser uma condição favorável à percepção, constituiria um empecilho à compreensão do próprio tempo em que se vive. A luminosidade excessiva do presente nos obriga a guardar certa distância dele, sob pena de termos o olhar ofuscado por ele. Logo, a proposta de contemporaneidade de Nietzsche é da ordem da "desconexão" e da "dissociação", 54 possibilitando a Agamben uma conclusão paradoxal a respeito do pertencimento ou não à contemporaneidade:

Pertence verdadeiramente a seu tempo, é verdadeiramente contemporâneo, aquele que não coincide perfeitamente com este, nem está adequado às suas pretensões e é, portanto, nesse sentido, inatual; mas, exatamente por isso, exatamente através desse deslocamento e desse anacronismo, ele é capaz, mais do que os outros, de perceber e apreender seu tempo. ${ }^{55}$

Para melhor elucidar sua proposta, Agamben vale-se de uma comparação baseada na fisiologia do olhar. Quando nos encontramos no escuro, nossas retinas acionam uma série de células (off-cells) que permitem a visão em ambientes de pouca luz. É a própria escuridão, portanto, que desencadeia o processo que nos permite enxergar em meio à obscuridade. Da mesma forma, as trevas do tempo presente podem nos ensinar uma nova forma de visão capaz de vencer a obscuridade. Por outro lado, para enxergar as trevas do tempo presente, é preciso

\footnotetext{
${ }^{53}$ Citado por AGAMBEN. O que é o contemporâneo? e outros ensaios, p. 58.

${ }^{54}$ Citado por AGAMBEN. O que é o contemporâneo? e outros ensaios, p. 58.

${ }^{55}$ AGAMBEN. O que é o contemporâneo? e outros ensaios, p. 59.
} 
neutralizar o excesso de luminosidade, pois "pode dizer-se contemporâneo apenas quem não se deixa cegar pelas luzes do século e consegue entrever nessas a parte da sombra, a sua íntima obscuridade". 56

Assim, da mesma forma como Zé Bebelo ensina a Riobaldo que só se pode sair do sertão "tomando conta dele adentro..."; ${ }^{57}$ e da mesma forma como Maninho ensina a MaisVelho que a única maneira de se acabar com a guerra é "fazer-lhe depressa, até no fim, gastála toda, matar-lhe"; 58 é a própria obscuridade do presente que nos ensina a nova forma de visão que nos permite enxergar no escuro.

Sob o signo do paradoxo, essa nova visão se realiza a partir de uma fratura ou de fraturas sucessivas da linearidade temporal. Dessa forma, pode-se dizer que "Aqueles que procuraram pensar a contemporaneidade puderam fazê-lo apenas com a condição de cindi-la em mais tempos, de introduzir no tempo uma essencial desomogeneidade."

Ao ser questionado sobre as contradições que caracterizam Nós, os do Makulusu, especialmente manifesta pela participação de Maninho e Paizinho em lados opostos da guerra de independência, Luandino Vieira atribui o fato ao próprio fluxo da história. Diz ele: "Não é por determinação minha, é a história. E isso é que me parece ser, estar lá no livro, que é o fluxo da história." ${ }^{, 60} \mathrm{O}$ sentido histórico, portanto, tal qual o entende Luandino Vieira, aponta não para as soluções sintetizadoras, mas para o contraditório, ou, como vimos insistindo, para o paradoxo, dispositivo, segundo Guimarães Rosa, capaz de suprir as lacunas de nossa própria linguagem.

A esta altura, ousamos, à guisa de conclusão, fazer um reparo à afirmação de Ricœur de que a narrativa, seja histórica, seja de ficção, promove uma "síntese do heterogêneo". O que se vê, na verdade, como resultado da atividade narrativa, é uma reunião do heterogêneo, ou, mais propriamente, a instauração do heterogêneo pela associação, no texto, de elementos divergentes, sem que haja, contudo, uma síntese apaziguadora que anule a divergência original, ou seja, a tendência própria da heterogeneidade que é possibilitar o convívio tensional entre elementos de natureza inconciliável, tratando, contudo, de preservar-lhes as diferenças. Como a metáfora viva, também a narrativa é instaurada pela conjugação

\footnotetext{
${ }^{56}$ AGAMBEN. O que é o contemporâneo? e outros ensaios, p. 63-64.

${ }^{57}$ ROSA. Grande sertão: veredas, p. 275.

${ }^{58}$ VIEIRA. Nós, os do Makulusu, p. 29.

${ }^{59}$ AGAMBEN. O que é o contemporâneo? e outros ensaios, p. 71.

${ }^{60}$ Citado por LABAN et al. Luandino. José Luandino Vieira e sua obra (estudos, testemunhos, entrevistas), p. 39.
} 
inesperada de elementos irredutíveis entre si e sobrevive ao desgaste justamente por não deixar que a tensão estabelecida entre esses elementos se esvaia.

Com o intuito de nos esquivarmos das ideias de homogeneização e de resolução dos contrários, uma e outra sugeridas pela palavra "síntese", sugeriríamos sua substituição pelo conceito de "totalidade contraditória", proposto por Cornejo-Polar. ${ }^{61}$ Para ele, a compreensão de literaturas como a latino-americana (e, acrescentaríamos por nossa conta, as africanas) não se perfazem por processos de homogeneização da diversidade, mas pela manutenção, em um mesmo corpo textual, do embate tenso e inevitável entre elementos distintos, por vezes contraditórios: colonizador e colonizado, assimilação e rejeição, oralidade e escritura, local e global etc.

De certa forma, foi o que procuramos mostrar ao longo deste trabalho com as leituras de Grande sertão: veredas e Nós, os do Makulusu. E, por extensão, valorizar não apenas o trabalho literário de Guimarães Rosa e Luandino Vieira, mas o de todos aqueles que souberam e sabem reconhecer no híbrido, na mescla, no contraditório, não um índice de decadência e degradação, mas a própria capacidade humana de se reinventar constantemente.

\section{RESUMÉ}

Lecture du temps et du paradoxe depuis la theorie ricœurienne. Dans Grande sertão: veredas, on analyze la création d'un point d'obsérvation éxterieur au flux temporel. Dans Nós, os do Makulusu, on étudie le procèss de fragmentation de la linearité temporelle à cause de l'éxperience traumatique de la guerre.

\section{MOTS-CLÉS}

Temps, paradoxe, Paul Ricœur, Guimarães Rosa, Luandino Vieira

\section{REFERÊNCIAS}

AGAMBEN, Giorgio. O que é o contemporâneo? e outros ensaios. Trad. Vinicius Nicastro Honesko. Chapecó: Argos, 2009.

ARRIGUCCI Jr, Davi. O mundo misturado: romance e experiência em Guimarães Rosa. Novos Estudos/Cebrap, São Paulo, n. 40, p. 7-29, nov. 1994.

\footnotetext{
${ }^{61}$ CORNEJO-POLAR. Mestizage, transculturacion, heterogeneidad, p. 56.
} 
AULETE, Caldas. Dicionário contemporâneo da língua portuguesa. 2. ed. brasileira. Rio de Janeiro: Delta, 1968.

BORGES, Jorge Luis. O livro dos seres imaginários. 3. ed. Trad. Carmen V. C. Lima. Porto Alegre: Globo, 1982.

CAMPOS, Augusto de. Um lance de "dês" do Grande Sertão. Revista do Livro, Rio de Janeiro, ano IV, n. 16, 1959.

CORNEJO-POLAR, Antonio. Mestizage, transculturacion, heterogeneidad. In: MAZZOTI, José Antonio; ZEVALLOS AGUILAR, U. J. (Coord.). Asedios a la heterogeneidad cultural: libro de homenaje a Antonio Cornejo-Polar. Philadelphia: Asociacion Internacional de Peruanistas, 1996.

DINIZ, Dilma Castelo Branco. A figura da elipse no Grande sertão: veredas. O Eixo e a Roda - Revista de literatura brasileira, v. 12, Belo Horizonte: FALE/UFMG, 2006, p. 175185.

FRASER, Julius Thomas. The genesis and evolution of time. Amherst: The University of Massachusetts Press, 1982.

GARBUGLIO, José Carlos. O mundo movente de Guimarães Rosa. São Paulo: Ática, 1972.

HOUAISS, Antônio (Org.). Dicionário eletrônico Houaiss da língua portuguesa. CD-ROM. Versão 1.0.5. Rio de Janeiro: Instituto Antônio Houaiss / Editora Objetiva, 2002.

LABAN, Michel et al. Luandino. José Luandino Vieira e sua obra (estudos, testemunhos, entrevistas). Lisboa: Edições 70, 1980. (Signos, 32)

LOBO, Manuel da Costa. Subsídios para a história de Luanda. Lisboa: Edição do Autor, 1967.

LORENZ, Günter. Diálogo com Guimarães Rosa. In: COUTINHO, Eduardo. Guimarães Rosa. Rio de Janeiro: Civilização Brasileira/Brasília, INL, 1983. p. $62-97$ (Coleção Fortuna Crítica, 6)

MENDILOW, Adam Abraham. O tempo e o romance. Trad. Flávio Aguiar. Porto Alegre: Globo, 1972.

MEYERHOFF, Hans. O tempo na literatura. Trad. Myriam Campello. São Paulo: McGrawHill do Brasil, 1976.

PERES, Phyllis. Transculturation and resistance in lusophone African literature. Gainesville: University of Florida Press, 1997.

POUILLON, Jean. O tempo no romance. Trad. Heloysa de Lima Dantas. São Paulo: Cultrix, 1964.

RICHARDS, I. A. The philosophy of rhetoric. London: Oxford University Press, 1965.

RICEEUR, Paul. Temps et recit. Paris: Seuil, 1983. Tomo I.

RICEEUR, Paul. Tempo e narrativa. Trad.: Constança Marcondes Cesar. Campinas: Papirus, 1994. Tomo I.

ROSA, João Guimarães. Grande sertão: veredas. 5. ed. Rio de Janeiro: José Olympio,1967.

SANTO AGOSTINHO. Confissões. Trad. J. Oliveira Santos e A. Ambrosio de Pina. São Paulo: Nova Cultural, 1999.

VIEIRA, José Luandino. João Vêncio: os seus amores. 2. ed. Lisboa: Edições 70, 1987. 
VIEIRA, José Luandino. Nós, os do Makulusu. 4. ed. Porto: Edições 70, 1985.

WHITROW, Gerald James. O tempo na historia: concepções sobre o tempo da pré-história aos nossos dias. Trad. Maria Luiza Borges. Rio de Janeiro: Jorge Zahar, 1993. 